\title{
Innovative education: A student approach
}

\author{
Anil G. Suryavanshi \\ The New College, Kolhapur (MS) India. E-mail: suryavanshi.a.g@gmail.com. \\ Accepted 17 May, 2012
}

\begin{abstract}
Education is an important part of human life. Education never dies, a person will die, but his or her valuable words, thoughts always remain in the through out the year. Today in India, there is tremendous change in education form bottom root to top. The pattern of education is also framed in new shape from kindergarten (KG) to post graduation (PG). The technology and development in the entire economic sector has a vast demand for highly skilled and talented human resource. India has invested a bulky amount in education field for sustainable development. India invested in education in general as well as higher education in particular in the first decades of independence. Innovation in education is the demand of global environment.
\end{abstract}

Key words: Higher education, life, highly skilled talent, sustainable development, innovation global environment.

\section{INTRODUCTION}

In the period of British emperor, the education system in India was completely different. The Gurukul system was completely neglected and the new education system came into existence. India's education system is divided into different levels such as pre-primary level, primary level, elementary education, secondary education, undergraduate level and postgraduate level. India's higher education system is the third largest in the world after China and the United States. Distance learning, elearning is also a feature of the Indian higher education system. Today, India has about 17000 colleges, 20 central universities, 217 State Universities, 106 Deemed to Universities and 13 institutes of National importance, more over 8 new Indian Institutes of Technology (IITs), 7 Indian Institute of Management (IIMs) and 5 Indian Institute of Science (IISC) to be started in the near future. The IIT's and IIM's are rated among the top in the world. These central government institutes are firstly established with assistance from Germany, Russia and United states Barun 2006; Encyclopedia of India and India 2009; Vrat, Prem 2006).

\section{Educative thoughts}

When we speak about innovation of education, it is essential to keep in mind that innovative is to devise the way which simplifies the task of touching the target. Innovative education not only provides productive human resource but also a well direction towards the future output. Carl (1962) and Shoemaker (1971) identified some important properties for innovation for example, relative advantage, compatibility, complexity, trialability and observability. A number of social thinkers and educationist have gone through the problems and feel about education more or less in the same way. Mahatma Gandhi, Rabindranath Tagore, Bertrand Russell, Maria Montessori and Friedrich Forbel are some of the noble thinkers whose views and ideas have been taken for developing a model for elementary education.

Mahatma Gandhi (1869-1948) mainly focused on selfsufficiency which paves ways for self employment. The educational philosophy of Mahatma Gandhi remarks that the education which covers all the subjects which concern our own country, our people, our life and our physical and social environment. The philosophy talked about unemployment, environment, ethical and cultural values and these properties are possible when we make innovations in the elementary education.

On the other hand, Rabindranath Tagore's (1861 1941) idea is nothing but a matter of truth. Tagore substantially focused on informal education like arts and crafts, drawing, painting, music, dancing etc. Developing spiritual unity in the nation was his main theme of 
Table 1. Plan expenditure on different sector of education between 1951 to 2007 (figure in \% in bracket - million of rupees).

\begin{tabular}{ccccccc}
\hline Period & Elementary education & Secondary education & Adult education & Higher education & offers & Technical education \\
\hline 1st plan 1951-1956 & $58(870)$ & $5(83)$ & - & $8(117)$ & $15(227)$ & $14(215)$ \\
4th plan 1969-1974 & $50(3743)$ & 0 & $2(126)$ & $25(1883)$ & $13(936)$ & $10(786)$ \\
7th plan 1985-1990 & $37(28494)$ & $24(18315)$ & $6(11421)$ & $10(20944)$ & $3(7398)$ & $14(10833)$ \\
8th plan 1992-1997 & $48(10940)$ & $24(52311)$ & $5(11421)$ & $10(20944)$ & $3(7398)$ & $10(21987)$ \\
9th plan 1997-2002 & $65.7(145233)$ & $10.5(23227)$ & $2.4(5204)$ & $10.3(22709)$ & $1.6(3492)$ & $1.4(3235)$ \\
10th plan 2002-2007 & $65.5(287500)$ & $9.9(43250)$ & $2.9(12500)$ & $9.5(41765)$ & $1.4(6235)$ & $10.7(47000)$ \\
\hline
\end{tabular}

Source: planning commission @ analysis of budget expenditure, Ministry of HRD, Govt. of India.

education. According to Bertrand Russell (1872 1970), the British philosopher-cum-mathematician has also gone through the problems of education. He focuses on the role of society in cultivating desirable and acceptable changes or changes in the social orders.

In the words of Maria Montessorie (1870-1952), a doctor of medicine from the University of Rome, she felt that education is the active help given to the normal expansion of the life of child. She believed that self education is the best device to educate the children.

Friedrich Forbel (1782 - 1852) a German educationist is known as the father of Kindergarten concept which means a garden for children in which they can develop. He suggested pre-school education for children below 5 years. He advocated play way, songs, essential for their learning Bhattacharya 2005; Services Marketing 2007 and Lakshmi 1989). Today in India, there is an innovative change in education from bottom root to top level of education system. In various states and cities, a number of play schools for children below 5 years are running very successfully. The pattern of education is also framed in new shape from KG to PG. The technology and development in the entire economic sector has a vast demand for highly skilled and talented human resource. It has made an over-burden on education to innovate the pattern of education right from elementary to higher education. There are a number of con-straints and problems and challenges before us but we have no option.

\section{Objectives of the study}

This paper is focusing on:

1) How government is planning to expend on elementary to technical education

2) To understand students approach about innovative education in modernized global environment.

\section{RESEARCH METHODOLOGY}

This research paper is mainly based on primary and secondary informative data related to education system. This research paper is descriptive in nature and based on some primary experiences in the field of education.

\section{Role of government planning commission on
education}

India has invested a bulky amount in education field for sustainable development. India invested in education in general as well as higher education in particular in the first decades of independence. Since independence the number of higher education institutes, universities increased simultaneously. Before 1976, education was the exclusive responsibility of the states. The constitutional amendment of 1976, which included National Programme on Education (NPE) in 1986 and Programme of Action (POA) was updated in 1992, the modifies policy envisages a national system of education to bring about uniformity in education making adult education a mass movement providing universal access retention and quality in elementary education synthesis of knowledge and inter disciplinary research in lighter education, starting more open universities in the states strengthening of the all India council of technical education (AICTE) encouraging sports physical education yoga and adoption of an effective evaluation method etc.

An Education Guarantee Scheme and Alternative Innovative Education (EGS and AIE) scheme has bear introduced to bring out of school children in the fold of elementary education (Barun 2006 and Bhattacharya 2005). Table 1 show that the government has planned expenditure of Rs. 4, 38,250 million in the education sector during the 10th plan period against Rs. 2, 20,960 million spent during the period 1997 to 2002. It is also observed that the government has gradually increased expenditure for primary education. According to 10th plan (2002 to 2007), the government has given mostly preference to elementary and technical education. As a part of the tenth Five year Plan (2002 to 2007), the central government of India outlined an expenditure of $65.6 \%$ of its total education budget of ₹ 438.25 billion (US $\$ 8.74$ billion) that is, ₹287.5 billion (US $\$ 5.74$ billion) on elementary education; $9.9 \%$ that is, ₹43.25 billion (US\$862.84 million) on secondary 
Table 2. National education budget (2011 to 2012).

\begin{tabular}{ll}
\hline \multicolumn{2}{c}{ National education budget (2011-2012) } \\
\hline Budget & ₹52,057 crore (US $\$ 10.39$ billion) \\
$\begin{array}{l}\text { General details } \\
\text { Primary languages }\end{array}$ \\
$\begin{array}{l}\text { System type } \\
\text { Established compulsory education }\end{array}$ & Federal, state, private \\
& April 1, 2010 \\
Literacy (2011) (\%) & \\
Total & 74 \\
Male & 82 \\
Female & 65 \\
& \\
Enrollment (N/A) & \\
Total & $(\mathrm{N} / \mathrm{A})$ \\
Primary & (N/A) \\
Secondary & (N/A) \\
Post secondary & (N/A) \\
& \\
Attainment (\%) & 15 \\
Secondary diploma & 7 \\
Post-secondary diploma & \\
\hline
\end{tabular}

education; $2.9 \%$ that is, ₹12.5 billion (US\$249.38 million) on adult education; $9.5 \%$ that is, ₹41.765 billion (US\$833.21 million) on higher education; $10.7 \%$ that is, ₹47 billion (US\$937.65 million) on technical education; and the remaining $1.4 \%$ that is, ₹6.235 billion (US\$124.39 million) on miscellaneous education schemes.

According to the United Nations Educational, Scientific and Cultural Organization (UNESCO), India has the lowest public expenditure on higher education per student in the world.

Recently the National Education Budget (2011 to 2012) has sanctioned ₹52,057 crore (US $\$ 10.39$ billion). This is also one of the most considerable factors in the education system. Table 2 shows the details:

\section{Public expenditure on education in India}

During the financial year 2011 to 2012 , the Central Government of India has allocated Rs 38,957 crores for the department of school education and literacy which is the main department dealing with primary education in India. Within this allocation, major share of Rs 21,000 crores, is for the flagship program 'Sarva Siksha Abhiyan'. However, budgetary allocation of Rs 21,000 crores is considered very low in view of the officially appointed Anil Bordia Committee recommendation of Rs 35,659 for the year 2011-12.

\section{Suggestive modern concept of innovative education}

Education is an important part of human life. Education never dies, a person will die, but his or her valuable words, thoughts always remain in the through out the world. Innovative education is the main requirement of society to make development and sustainable growth in future. According to my knowledge, innovative education should be student, business, profession, market and technology oriented but complementary to the environment. Figure 1 indicates the structure of modern concept of innovative education, is in detail as follows:

\section{Student oriented education}

Students are soul or center of education institutions of the world. If there are no students, there will be no education system. Students are the property of nation, meanwhile they are well known as 'National Asset' of nation. They are the pillars to build the nation. The innovative, energetic, skilled and developed students will lead to nation; hence the education system has to provide student oriented education in global environment. Only theoretical knowledge is not sufficient, it requires practical orientation for each stream of education. Even though, if we started vocational training from elementary level of education, it will be more productive in futuristic education period.

In this globalize environment students have a highly qualitative brain, sometimes called as computer brain. It is the prompt duty of teachers to feed maximum practical knowledge to students. It will give proper opportunity to students after getting their degrees in any field. I would like to suggest that the syllabi should be divided into $60: 40$ proportions, it means $60 \%$ weight to theory and $40 \%$ will be practice. The learning plan of teacher must include approaches, procedures, strategies, techniques and manipulation of other variables of the learning environment.

Teacher should focus on motivational aspects in addition to the instructional aspects. Innovative teaching techniques, objective assessment and communication, matching of function with aptitude and capability, autonomy to the learner team work, suitably designed changes in environment etc; it means teachers should use motivational process for teaching (Figure 2). 


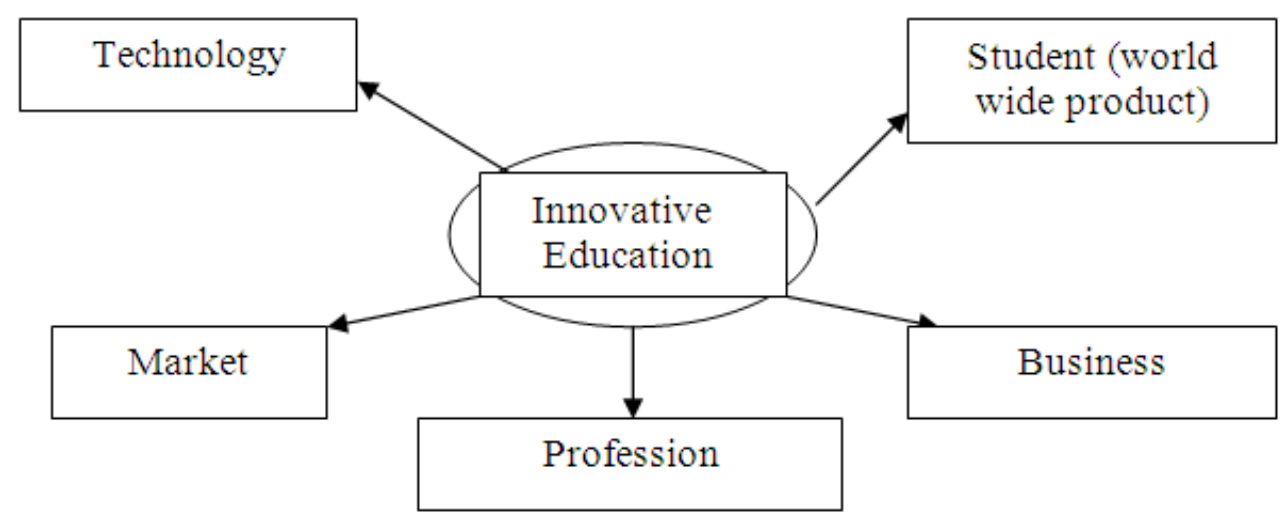

Figure 1. Modern concept of innovative education.

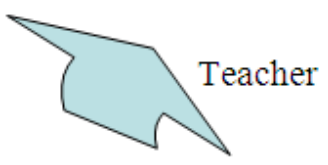

Global

Opportunities

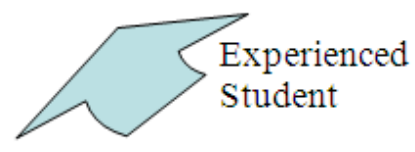

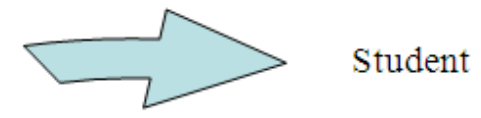

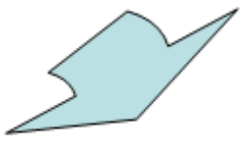

Classroom

knowledge
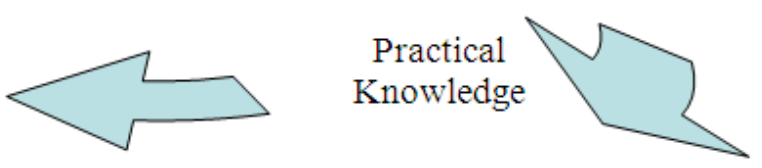

Figure 2. Student oriented innovative education.

\section{Business oriented education}

Business is classified into industry, trade and commerce. The education should be business oriented; it means it is inclusive of business laws, how to frame the policy, procedure of launching of new business or industry, requirements of business, business analysis, import-export business etc. Innovative education will help in practices; therefore, we have to arrange interaction between industry and institution regularly. Students have to acquire knowledge to develop the business by analyzing different situations which arises into business organization. Institutions should assign monthly, quarterly or six monthly minor projects on business analysis. It will update the knowledge of students and they will understand the current economic conditions and situations.

The procedure of merger and acquisition, collaboration of various companies, access of IT based companies are providing maximum opportunities of employment with high pay packets in India. As a result, business is demanding dexterous human resource; this need can be fulfilled by innovating and generating the new ideas in education field.

\section{Education through business model}

I think that the afore-mentioned model if implemented in routine business life will provide the best results towards organization and society. It will increase the efficiency of business, profitability and motivate the manpower at work (Figure 3 ). Through this, we can develop the syllabi and can change infrastructure of education system.

\section{Profession oriented education}

Practical work is one of the vital components of any professional curriculum. Its importance has, over the years, been realized by both the curriculum designer and the teacher. The ratio has been debated as 40:60, 50:50 or 60:40 etc. Professional education needs to be "learning through experience". After graduation or post graduation if students look for professional courses, they will waste their time in acquiring knowledge more. But it will be easy for them if they "walk with experienced stick'. "Learning to learn" would call for innovations in curriculum design and changing strategies of course offering. Today instead of Chartered Accountant (CA), Institute of Cost and Work Accountant of India (ICWA) 


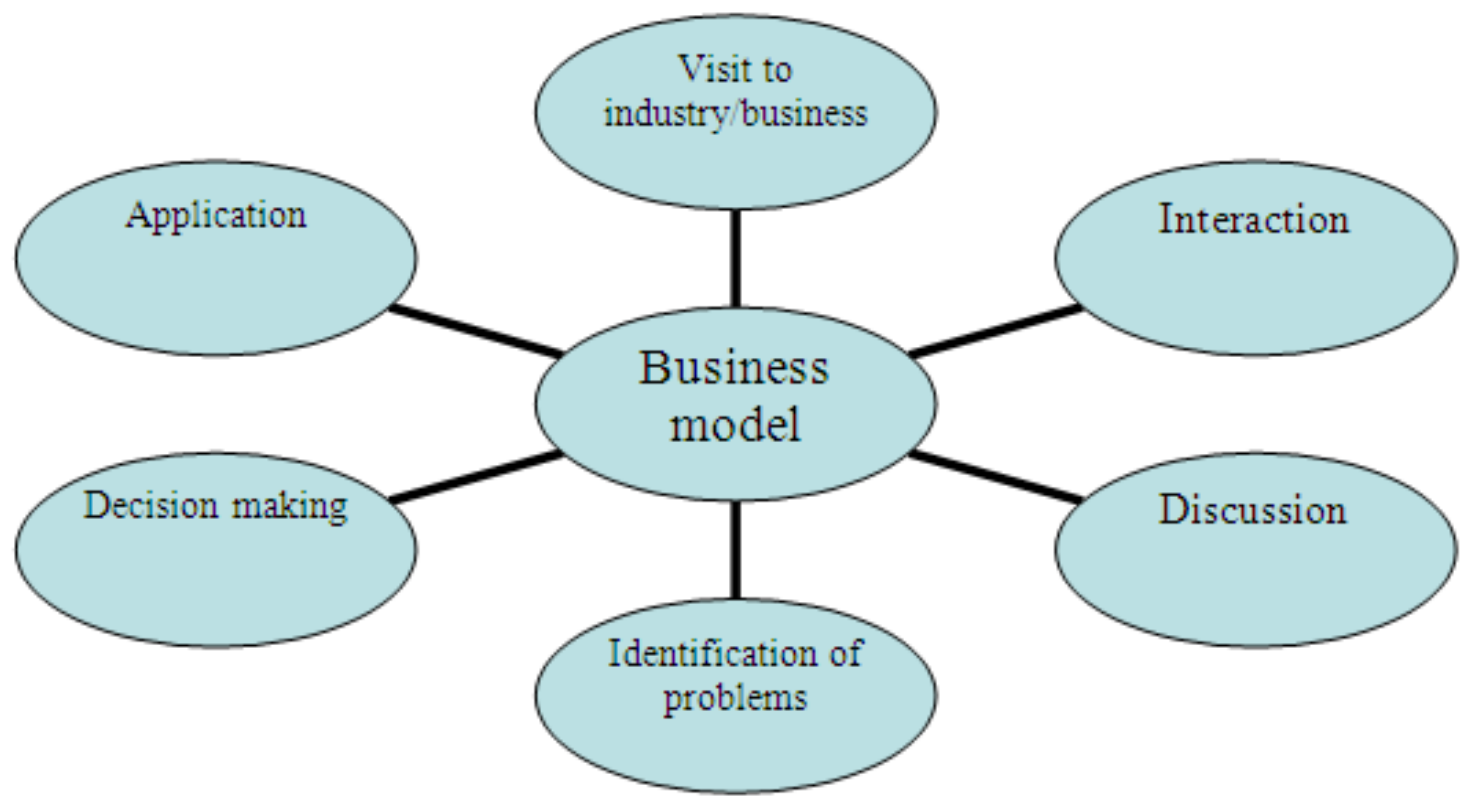

Figure 3. Business model for innovative education.

and Company Secretary (CS), students are ready to get more professional knowledge through Bachelor of Business Administration (BBA), Master of Business Administration (MBA) and other based management courses. The increasing number of management institutions becomes a problem to students in choosing the course and institution. The management courses are spread all over the world, but we can loose the importance of management education if we permit to enter a number of management institutions in education sector.

\section{Technology oriented education}

The globalize knowledge economy is characterized by continuous change and development of technology and organizational change. Therefore, there is a need of flexible learning technology. For preparing knowledge workers, the education system needs reforms. First is to create the important linkage between education and labour market so that the learning system gets continuous feedback about the needs of employees and employers.

Secondly, the technical education system needs to offer variety of skill updating course using various modes and exploiting the full potential of information and communication technologies (ICT). ICT offers new and innovative modes of learning for all students at all educational levels.

The application of modern teaching aids like LCD projector, smallest format $(16 \mathrm{~mm})$ movie, audio and video cassettes, the computer multi media instructional system (MMIS), computer assisted instruction (CAI) are important to be used for effective teaching. Through elearning, computer based training (CBT), web based training (WBT), distance or online learning process, we can exchange or share ideas and information across local to national and international level Lakshmi (1989). As we know technology is a backbone of nation's industry for prosperity and growth. Apart from some disadvantages of technology adoption, really there is need of technology for innovation of the entire economic sector. Thus, innovative education is not a thirst of only education system but also it is of whole world.

\section{Market oriented education}

Students are the product of well educational systems of the world. They should have market demand. It means, well shaped, skilled and well developed students have always market demand and global opportunities of placement. The students should be aware of market situations. The students are selected through campus interview but sometimes, they will not show the same potential or performance at the work time in the company, hence they should have to develop their own quality and potential by acquiring innovative techniques.

\section{Conclusion}

World is changing fast, it means each human-being/ person is adopting the global circumstances. The "Borderless World" will impart and open the doors for 
education. The quantity is not important; the quality is the soul of innovative education. The impact of liberalization, privatization and globalization results to make distinguish changes in economy as well as education sector. The change in education is a must for adopting the global environment. Today number of private institutions, foreign institutions are entering in India and competing with existed education institution. It is the opportunity to survive with the best and accept the global challenge of innovative education. The transformation of traditional way of education into modern is the right key for success in the education system. Today, there is a diversion of mind of students to choose right institute and course. Therefore, there is a need to introspect the education system for surviving in the corporate world and how to direct the students in this global flow for getting esteem to institution. Indian government is expending crores of rupees on education and therefore there is the need to provide innovative education streams and knowledge areas towards the next generation. It can be concluded that the spending more on education means developing an innovative nation of talents.

\section{REFERENCES}

Barun Kumar De (2006). Public Systems Management-, (New Age International $(P)$ Limited, Publishers.

Bhattacharya SK (2005). Education Technology: -Abhishek Publication, Chandigarh-17.

Services Marketing (2007). Education Marketing, S. M. Jha,, Himalaya Publication House. Pp .452-457.

Lakshmi S (1989) Innovations in Education, Sterling India pp.52-54

Literacy Rate and Gender Gap in Sechduled Castes in India, (viewed on 9 Mar 2011),

Encyclopedia of India (vol. 2) edited by Stanley Wolpert, 23-28, Thomson Gale: ISBN 0-684-31351-0.

Vrat, Prem (2006), "Indian Institutes of Technology", Encyclopedia of India (vol. 2) edited by Stanley Wolpert, 229-231. 